\title{
Modification of the Classical Theory of Metalworking
}

Karol Vasilko (ORCID: 0000-0002-0750-9075), Zuzana Murčinková (ORCID: 0000-0003-0306-7975)

Technical University of Košice. Faculty of Manufacturing Technology, 08001 Prešov, Bayerova 1, SR, E-mail: karol.vasilko@tuke.sk, zuzana.murcinkova@tuke.sk

The paper derives mathematical and graphical relationships between technological parameters and results of metalworking, in the application of progressive cutting materiáls based on coated cutting tools made of sintered carbide and cutting ceramics. The development of new cutting and machined materials leads to new perspectives on their interaction in the machining process. This process leads to patterns between cutting conditions and machined results. These need to be defined and used in favor of efficient machining of mechanical components in practice.

Keywords: machining, chip formation, tool durability, cutting forces, material machinability

\section{Introduction}

Recently prefered theory of metalworking is based on the experience of this technology obtianed in the period of formation of a high-speed steel (Taylor [24] Time [25]). Its characteristics is preferring linear dependences among the technological conditions and results of metalworking. These have been obtained by a small number of experiments. The development of cutting and cut materials, the application of highly rigid metals, have required to considerably modify all the attributes of these theories. Let us try to define essential changes of approaches to recent evaluation of laws of metalworking.

\section{Chip formation}

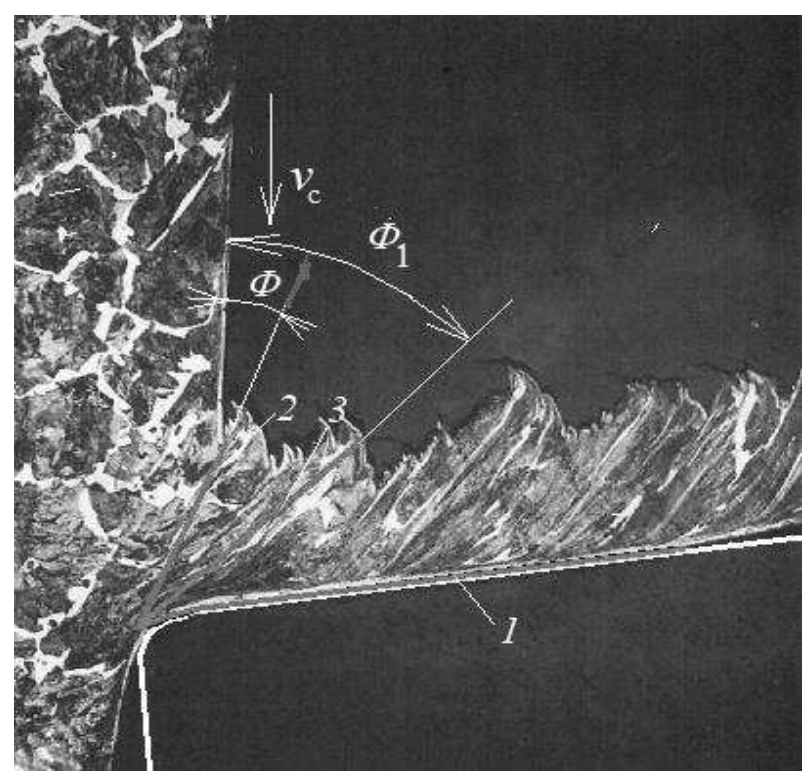

Fig. 1Metallographic thin section of the zone of chip formation. Materisl C45, 1-outer friction between the tool face and chip, 2 - intercrystallic friction, 3 - intracrystallic friction. $\phi$ angle of ,slide plane", $\phi_{1}$ - angle of chip texture. $\gamma_{\mathrm{n}}=-6^{0}$, $v_{c}=120{\mathrm{~m} . \mathrm{min}^{-1}}^{-1}$
Well-known models of chip formation (Bobrov [2], Brix [3], Glebov [9], Degner [4], Dmochovski [6]) used to be simple geometric schemes which cannot describe the complex process and effect of plastic deformation of cut material in front of the cutting wedge based on the observation of deformation domains in the direction of maximum tensions. Deformation field is not homogenuous. The first realistically dynamic model of chip formation based on plastic circumfluence has been created by Loladze [18]. Let us try to define the process of chip formation as a tribological mechanism [1],[14]. Such a mechanism can be described by Fig. 1 .

In Fig. 1 there is a metallographic thin section of the zone of chip formation during cutting a carbon steel C45.

Three characteristic areas of friction can be characterised. The intensity of outer friction on the surface 1 depends on the value of friction coefficient between the cut and cutting materials. It is a source of heat which heats the tool and the chip, caused the decrease of the tool cutting wedge rigidity and its wear on the face. Friction along the slide line 2 , leaned under angle $\phi$ is primarily happening along the grain borders and is basically the reason of the formation of the chip in the particular configuration. From there friction heat spreads into the chip and cut-off layer, which consequently turns into the chip. Along the line 3, oriented under the texture angle $\phi_{1}$, friction is happening inside the metal grains in the conditions of high temperatures, probably with small coefficient of internal friction. The result presents the texture of prolonged metal grains in the chip and much thicker chip $h_{1}$ than the thickenss of the cut-off layer $h$. It can be supposed that in this area the material which is being worked poses the least resistance against the deformation. This model enables to explain the formation of elementary or fluent chip according to the smallest value 
of friction coefficient in the observed zone, where priority deformation happens. In this case, the smallest value of friction coefficient in zone 3. There occurs adiabatic slide.

A well-known measure of a global intensity of chip plastic deformation is the parameter ,chip compression", historically defined as [3],[5],[11],[13],[23].:

$$
k=\frac{h_{1}}{h}
$$

Where:

$h$ is the thickness of cut-off layer, $\mathrm{mm}$

$h_{1}-$ chip thickness, $\mathrm{mm}$

It is possible to quite precisely define how fluent the chip is. However, recently materials with high rigidity and strenght, which form elementary chips with periodic slides, divided or little fluent are machined many times. An example is presented by a chip formed when machining titanium alloys (Fig. 2).

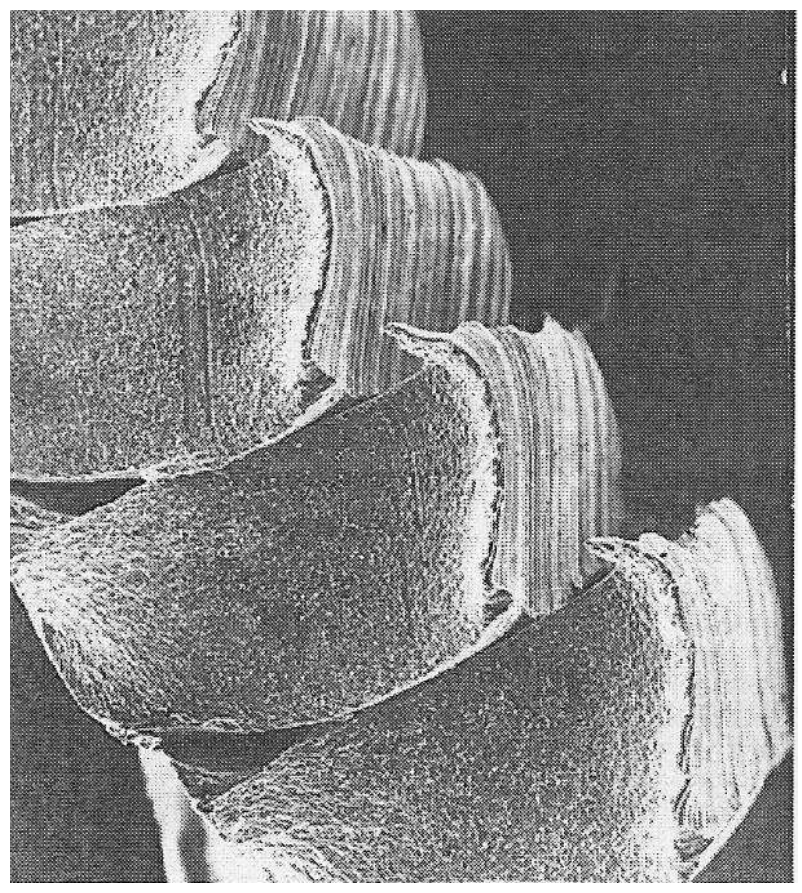

Fig. 2 Chip formed during machining titanium alloy

It is a problem to determine the exact value of $h_{1}$ in this case.

The starting point is to turn to analytical determination of $k$ with the use of the following formula:

$$
k=\frac{1000 \cdot m_{1}}{l_{1} \cdot \gamma \cdot S}
$$

where:

$m_{1}$ is the weight of recorded chip of a certain length, g,

$\gamma$ - cut material density materiálu, g. $\mathrm{mm}^{-3}$,

$S$ - surface of cut thin section, $\mathrm{mm}^{2}$,

$h_{1}-$ recorded chip lenght, $\mathrm{mm}$.
Then, a reliable dependence can be obtained $k-v_{c}$ (Fig. 3).

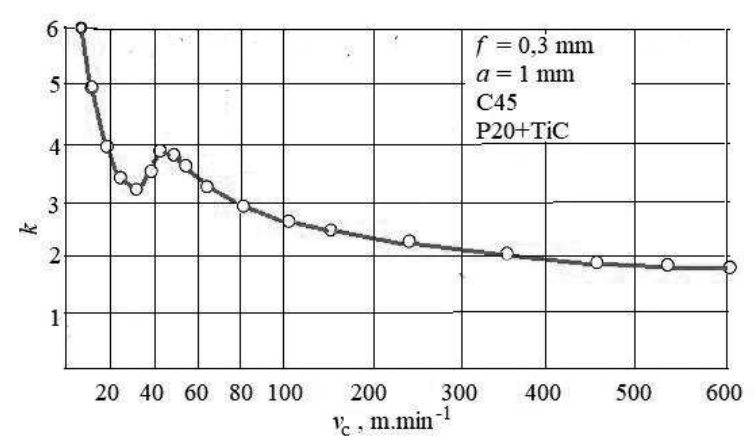

Fig. 3 Experimental dependence of chip density of cutting speed

\section{Cutting forces}

The course of the dependence of cutting forces on cutting conditions is not linear [19],[22] An example of experimental dependence of all three elements of cutting force on cutting speed is shown in Fig. 4. The course resembles the dependence shown in Fig. 3 and is probably linked with the change of strenght of cut material in front of the tool cutting wedge (or cutting temperature). Maximum values lie in the area of minimal cutting speeds where the cut material has room temperature, i.e. also standard strenght. The increase of cutting speed leads to the decrease of material strenght and cutting force. Vice versa, further increase of cutting speed leads to the material relaxation, increase of plasticity and cutting material attachment. This leads to the formation of a built-up edge and steep increase of cutting force. After its removal and further decrease of the cut material strenght, cutting force continually decreases in the zone of contact with the cutting tool. In the observed case, two areas of minimal cutting force can be identified at the cutting speed cca $20 \mathrm{~m} \cdot \mathrm{min}^{-1}$ and above the value $v_{\mathrm{c}}$, exceeding 80 $\mathrm{m} . \mathrm{min}^{-1}$. The first area can be utilised only sporadically because it leads to prolonged machining time. The second area is limited only by such high cutting speed, which leads to considerable decrease of tool durability.

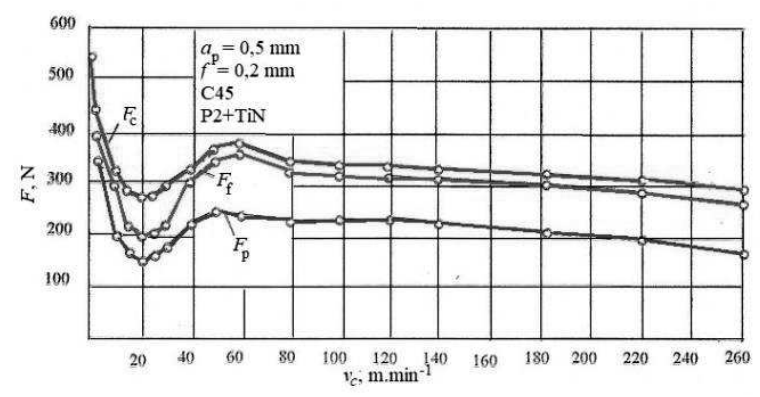

Fig. 4 Actual experimental dependence between the elements of cutting force and cutting speed. 


\section{Cutting tool durability}

Historically, the tool durability is observed by a classical Taylor formula $T-v_{c}$, which is modified in a double logarithmic network as a linear one [10],[16],[17]. Detailed observation of recent cutting materials provides much more complex dependences.

In Fig. 5 there is a typical experimental dependence $T-v_{c}$, obtained during machining a steel steel by an uncoated sintered carbid tool P20.

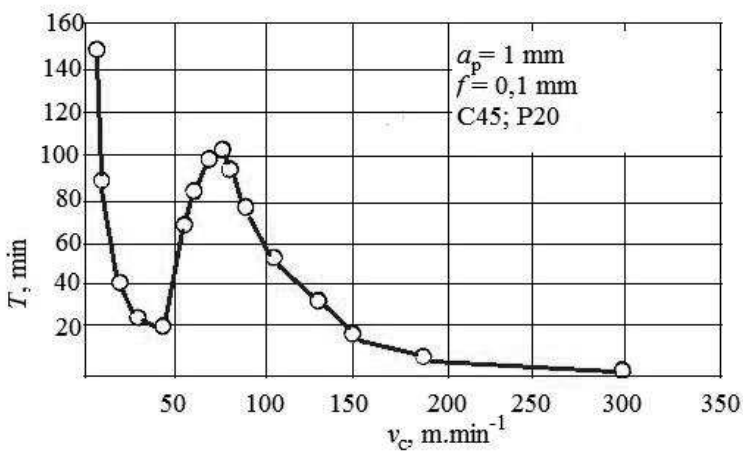

Fig. 5 Typical example of experimental course of dependence $T-v_{c}$, obtained during turning steel by a tool made of sintered carbid.

Two considerable maximums of durability can be seen, at minimal cutting speeds and cutting speed close to $80 \mathrm{~m} \cdot \mathrm{min}^{-1}$. The first one is the result of brittleness of unheated cut material which is in brittle state, forms an elementary chip with a short contact with the tool face. This cutting speed cannot be used considering the prolongation of machining time. The other area presents optimal cutting speed. With further increase of cutting speed, the durability of cutting tool decreases sharply. In presented case, the limit value is $300 \mathrm{~m} \cdot \mathrm{min}^{-1}$, where it reaches value under $1 \mathrm{~min}$.

The following dependence for the use of a coated tool (Fig. 6) has a similar course, however, it is shifted upwards, towards higher durability values, and to the right, to the area of usable cutting speeds.

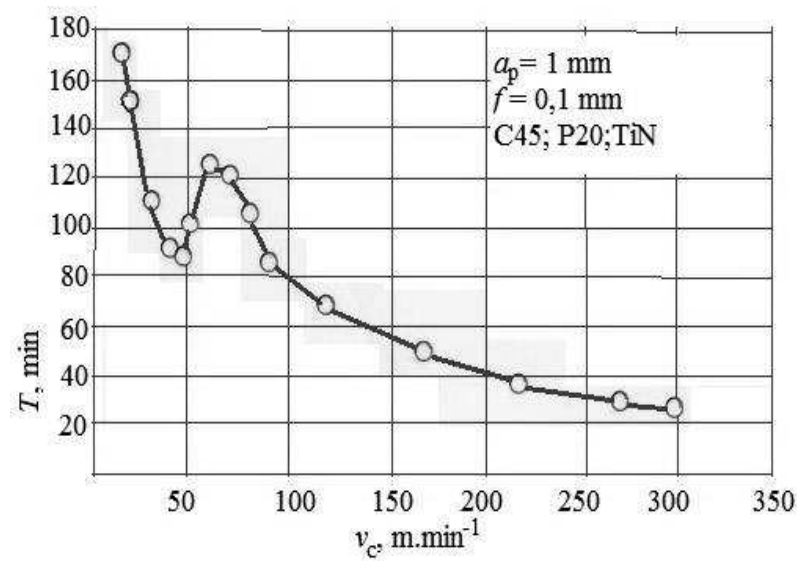

Fig. 6 Course of T. $v_{c}$ dependence for the use of a coated tool made of sintered carbid.
To complete the picture, Fig. 7 shows a similar diagramme for the tool made of coated ceramics. Again, an increase of durability in whole range of cutting speeds and further shift of durability maximum towards higher cutting speed can be seen.

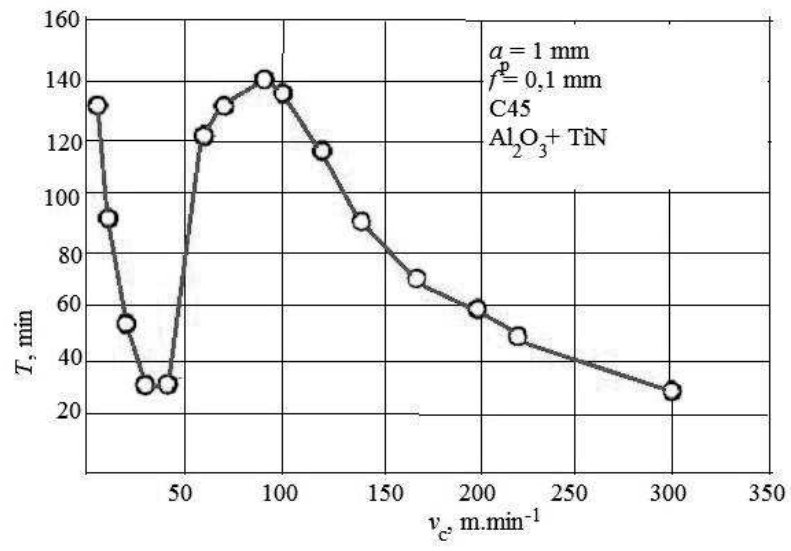

Fig. 7 Experimental dependence of durability of caoted ceramic tool on cutting speed [7].

The differences in the course of different curves are large, but the character of curve courses is identical. The diagramme enables to determine cutting speeds which correspond with maximum and minimum durability of different cutting materials and other areas of particular values of tool durability.

It is interesting to observe the course of $T-\mathrm{v}_{\mathrm{c}}$ dependence at super hight cutting speeds. The correspoding diagramme in linear and double logarithmic systems are shown in Fig. 8 and 9.

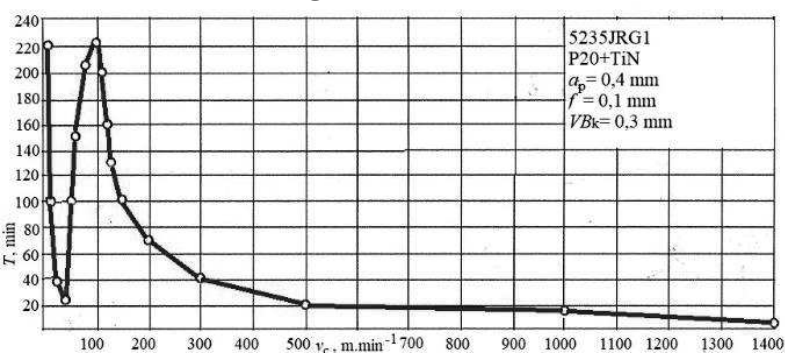

Fig. $\boldsymbol{8}$ Experimental dependence of $T-v_{c}$ in maximum reachable range of cutting speeds.

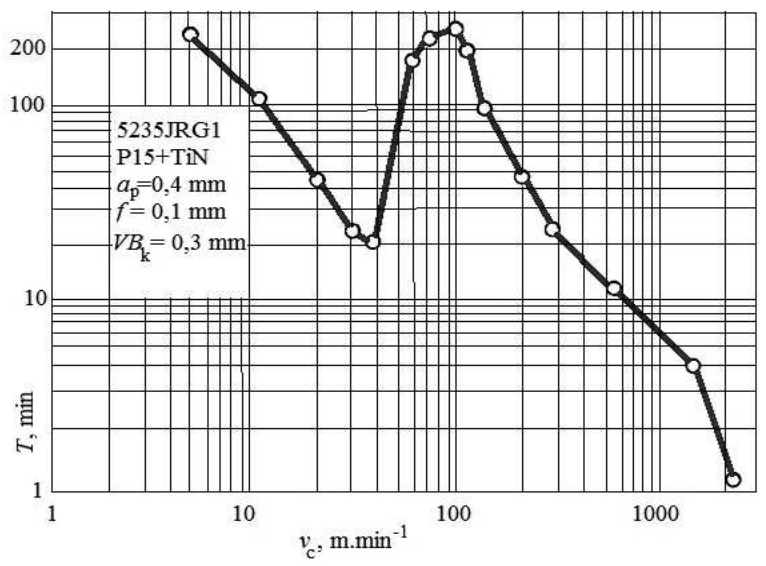

Fig. 9 Identical dependence in double logarithmic coordinate system. 
In comparison with previous dependences, a considerable decrease in durablity at high cutting speeds can be seen. At $v_{\mathrm{c}} \geq 1000 \mathrm{~m}$.min tool durability reaches the values of only several seconds.

The used shift considerably influences the position of maximal and minimal durabilities in connection with cutting speed. It enables to select optimal (different) cutting speed at roughing and finishing.

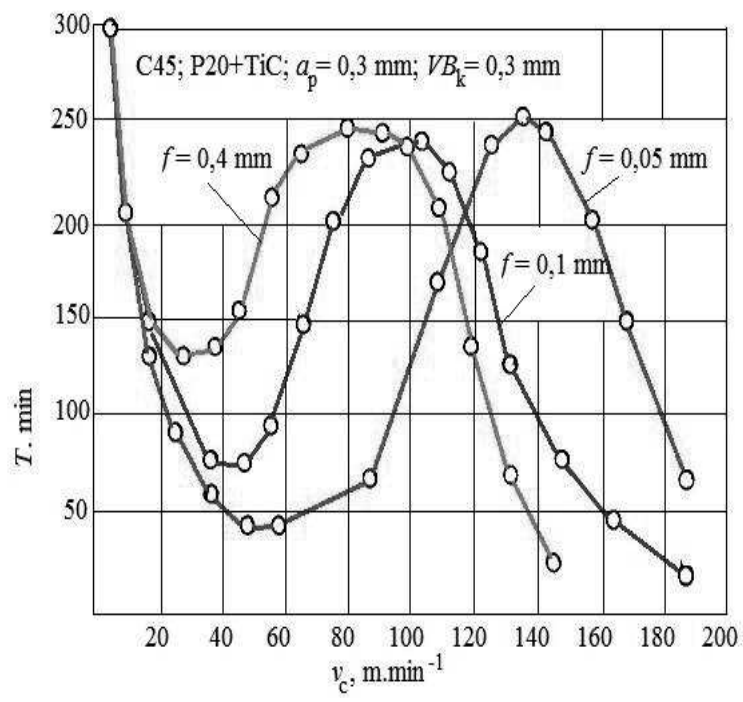

Fig. 10 Experimental diagramme of depenedence of tool durability on cutting speed at different tool shifts.

The construction of one complex $T-v_{\mathrm{c}}$ dependence reuires the experimental construction of at least 20

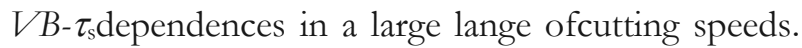
We did it, at least for the basic types of current tool materials. he complex diagram looks as follows - fig. 11.

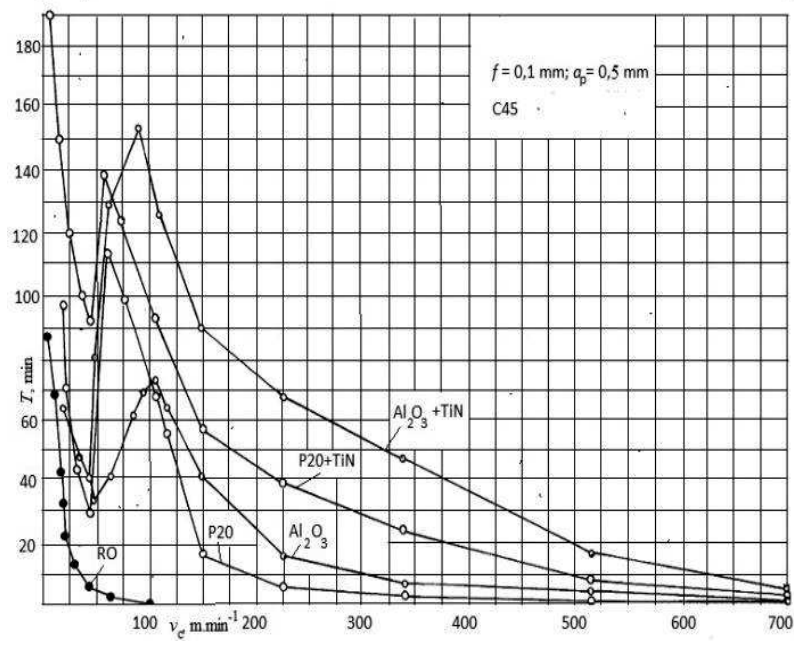

Fig. 11 A set of complex $T-v_{c}$ dependences for classical and coated tools $[7]$

It can be seen that the position of maximum durability is different for each cutting material.The range of usable cutting speeds can be recommended for each cutting material from the maximum of the curve up to about 3 values on the right. Of course, with the axception of high-speed stell (RO).

\section{Machined surface quality}

The shift is a limiting technological parameter, on which the height of uneveness of machined surface of the workpiece depends. Traditionally, to determine this dependence, the following theoretical formula is applied [10],[13],[27].:

$$
R z=\frac{f^{2}}{8 . r_{\varepsilon}} .
$$

Let us verify it practically. Experimental dependence $R \approx-f$ for the tools with different diameters of tip rounding is shown in Fig.12.

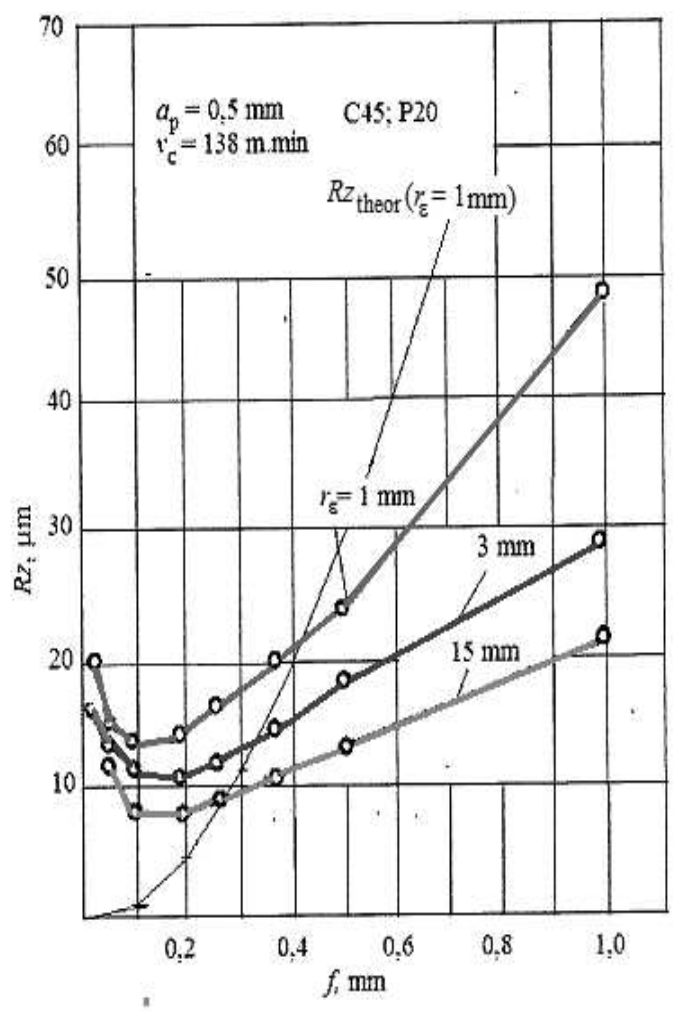

Fig. 12 Experimental and theoretical dependence $\mathrm{R}_{z}=f(f)$.

As it can be seen, experimental courses are very different from theoretical ones. The difference is in the area of small shifts. The dependence does not end at zero and with shifts less than $0.1 \mathrm{~mm}$ the $\mathrm{Ra}$ is increasing. The reason of this fact is that we are getting into the conditions when the diameter of cutting edge rounding $r_{n}$ is very close in size to the thickness of the cut-off layer. (For high-speed tools, vhere was a greater agreement between the experiment and the theoretical course, because the tool could be sharpened to $r_{n}$ significantly smaller than $\left.0,1 \mathrm{~mm}\right)$. The chip is deformed more and the material is being pushed under the cutting wedge. Behind the cutting wedge, there 
occurs a formation of ,scales“ on the machined surface by the influence of flexible and plastic material deformation and its adhesive attachment to the tool material. This phenomenon is described as ,the minimum chip problem". At the same time it is possible to observe the difference at large shifts. In the observed case the concord occurs only at the value $f=$ $0.41 \mathrm{~mm}$. Theoretical course does not correspond with the actual dependence.

As it can be seen in Fig.11, further decrease of the shift towards minimal values at finishing, quality of machined surface does not improve, on the contrary, $\mathrm{Rz}$ is increasing and more over, the machining time for defined workpiece surface prolongs. A more detailed statistic observation of a similar dependence is illustrated for instance by a diagramme obtained during machining by a ceramic tool, Fig.13.

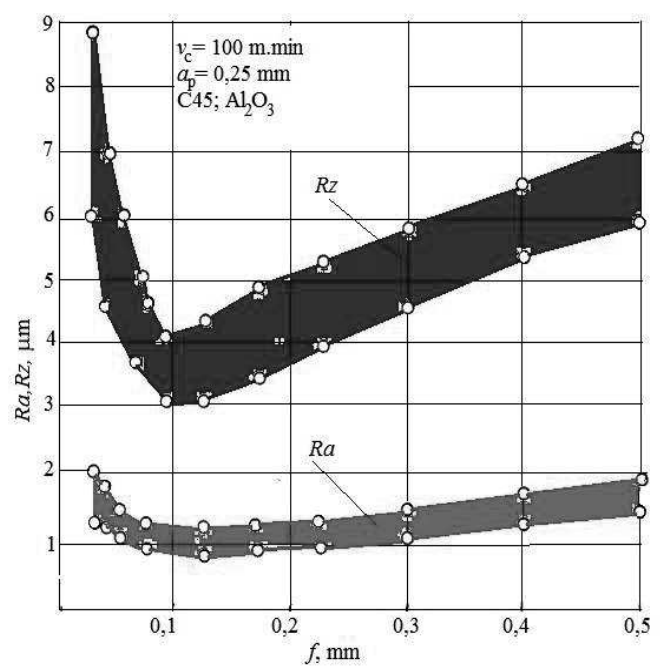

Fig. 13 Dependence of $\mathrm{R}_{\mathrm{z}}$ and $\mathrm{R} a$ on the shift during finishing with a ceramic cutting tool.

The increase of the uneveness of machined surface at small shifts is greater because ceramic tools have much larger diameters $r_{\mathrm{n}}$. Similar situation is true for coated tools made of sintered carbid because the coating increases $r_{\mathrm{n}}$.

Let us try to replace the original theoretical formula for $R_{z}$ (according to which the shift has been calculated so far) by a practical formula.

By mathematical analysis of similar experimental courses, the following formula has been derived [11]:

$$
R z=\frac{f^{2}}{8 . r_{\varepsilon}}+\frac{h_{m}}{2}\left(1+\frac{r_{\varepsilon} \cdot h_{m}}{f^{2}}\right)
$$

where $h_{\mathrm{m}}$ is the thickness of the cut-off chip corresponding to the curve minimum.

The depiction of this formula, at $r_{\varepsilon}=0.8 \mathrm{~mm}$ and $h_{\mathrm{m}}=0.1 \mathrm{~mm}$ is shown in Fig. 14 .

In concord with the experiments, if $h_{\mathrm{m}}=0.1 \mathrm{~mm}$ is substituted into the formula, the following dependence is formed:

$$
f=\sqrt{8 \cdot R z \cdot r_{\varepsilon}-0,1 \cdot r_{\varepsilon} \sqrt{R z^{2}-0,1 \cdot R z}}
$$

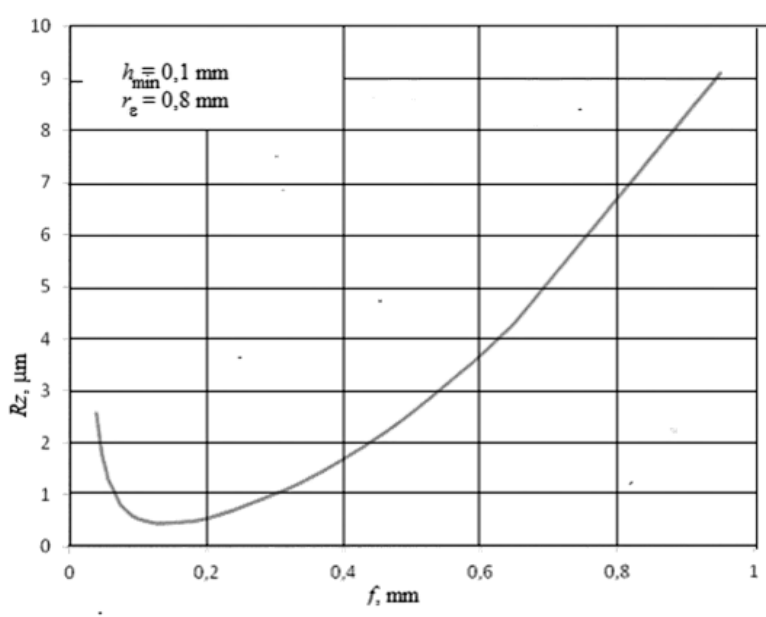

Fig. 14 Dependence curve $\mathrm{R}_{\text {zff, }}$ obtained from the formula (4)

The second parameter, following the observed parameters of surface uneveness, is cutting speed. To obtained a detailed dependence, face turning of the workpiece with sufficient diameter can be used, see Fig. 15. At selected turning frequency $n$, cutting speed fluently changes in a large scale, according to the formula:

$$
v_{c}=\frac{\pi \cdot D \cdot n}{1000},{\mathrm{~m} \cdot \mathrm{min}^{-1}}^{-1}
$$

Complete dependence can thus be obtained from one workpiece.

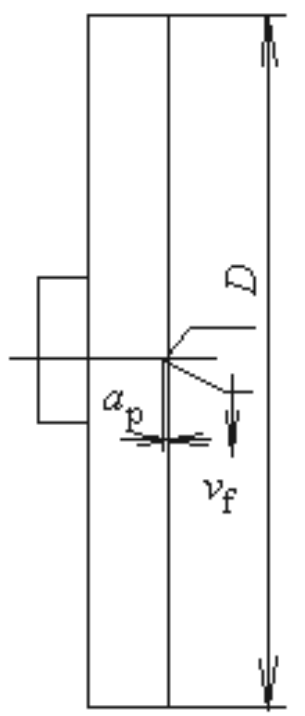

Fig. 15 Sample workpiece to observe the influence of $v_{c}$ on $\mathrm{R}_{z}$

Typical diagrammes of dependences of $\mathrm{R} \approx$, or $\mathrm{R} a$ on $v_{\mathrm{c}}$ are shown in Fig. 16 and 17.

The area of minimum surface uneveness is around $v_{\mathrm{c}}=30 \mathrm{~m} \cdot \mathrm{min}^{-1}$ and continues again to the same level until it crosses the cutting speed $100 \mathrm{~m} \cdot \mathrm{min}^{-1}$. 


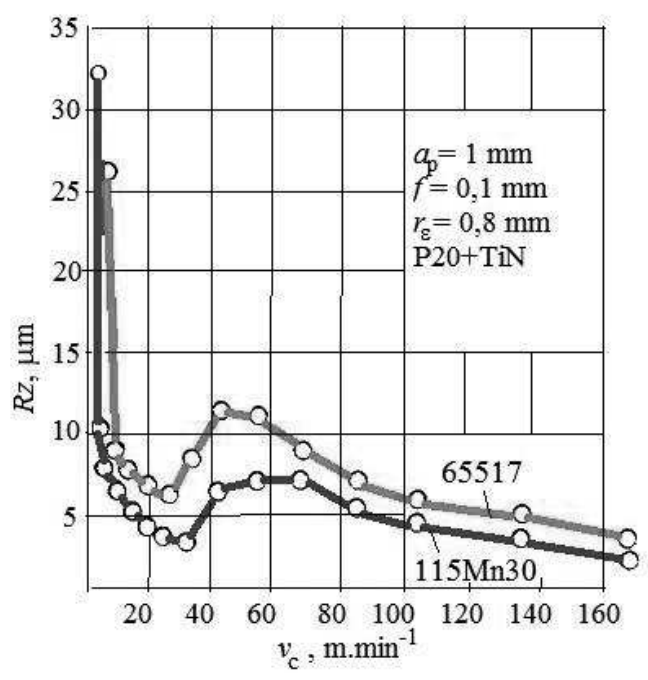

Fig. 16 Experimental dependence of greatest height of profile uneveness on cutting speed obtained during machining steels $11 S M n 30$ and 65517 with a tool made of sintered carbid.

It can be seen that at minimal cutting speed, the surface uneveness increase. It is probably the result of the formation of fissures in workpiece in front of the cutting wedge. The surface worsens considerably. Next, the size of uneveness steeply decreases and reaches minimum at $v_{\mathrm{c}}$ around $20-30 \mathrm{~m} \cdot \mathrm{min}^{-1}$. Another further steep increase of $R a$ and $R z$ is caused by the formation of a built-up edge on the cutting wedge. After exceeding the cutting speed $70 \mathrm{~m} \cdot \mathrm{min}^{-1}$, both parameters continually decrease. It means there exist two areas with minimal values of uneveness heights, small cutting speeds (and temperatures), before the occurence of adhesive attachment of tool and cut materials, and high cutting speeds corresponding with plastic circumfluence of chip material. This can be used in the selection of cutting speeds in practical conditions.

Fig.17 shows a similar dependence obtained during machining with ceramics, in higher range of cutting speeds. Formally, the character of the curve is identical, however, shifted towards the higher values of $v_{\mathrm{c}}$ and $\mathrm{R}_{z}$.

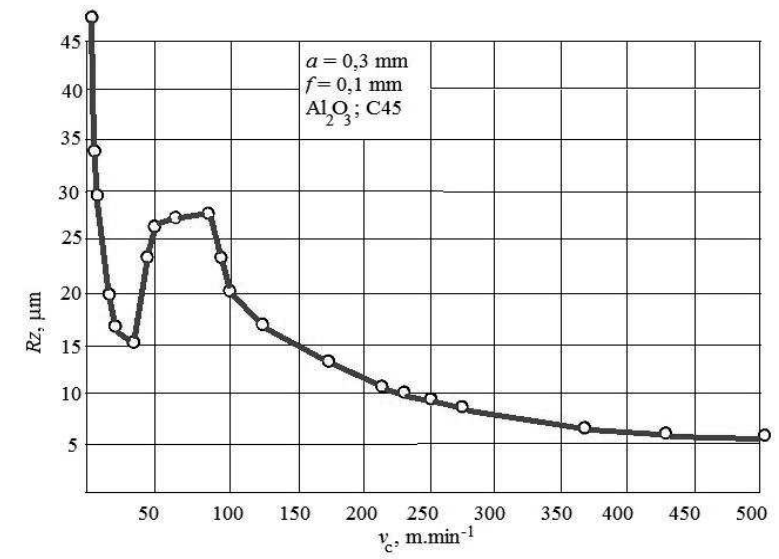

Fig. 17 Experimental dependence $\mathrm{R}_{z}=f\left(v_{c}\right)$, obtained $d u$ ring turning with sole ceramics.
The course of summary dependence of $\mathrm{Rz}$ on $\mathrm{v}_{\mathrm{c}}$ and $\mathrm{f}$ is interesting, see Fig.18.

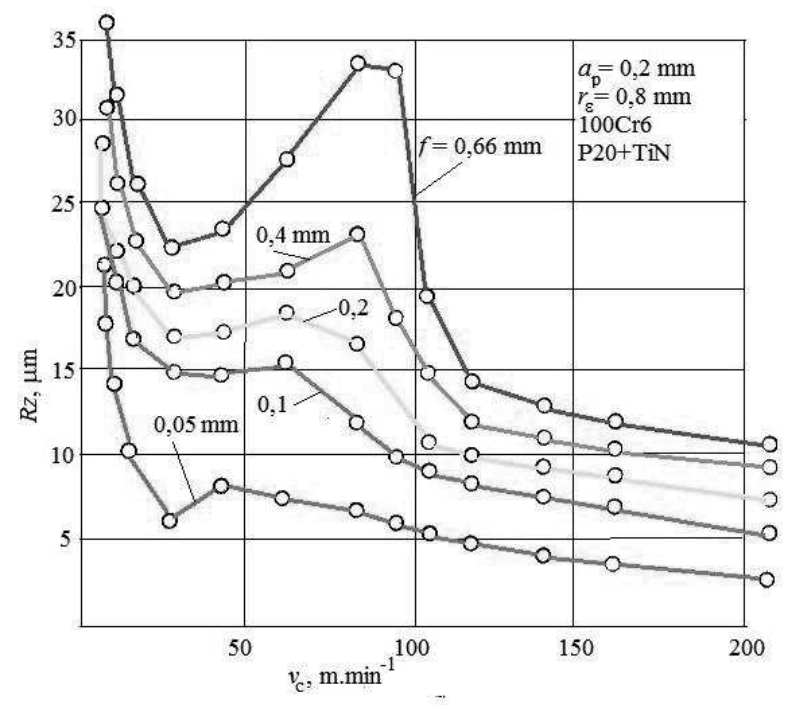

Fig. 18 Summary experimental dependence of $\mathrm{Rz}$ on cutting speed and shift.

By the increase of the shift, the greatest height of uneveness grows in whole range of cutting speeds and the maximum shifts towards higher values of cutting speeds. The diagramme enables to select a cutting speed which is optimal towards the defined shift.

\section{Material machinability}

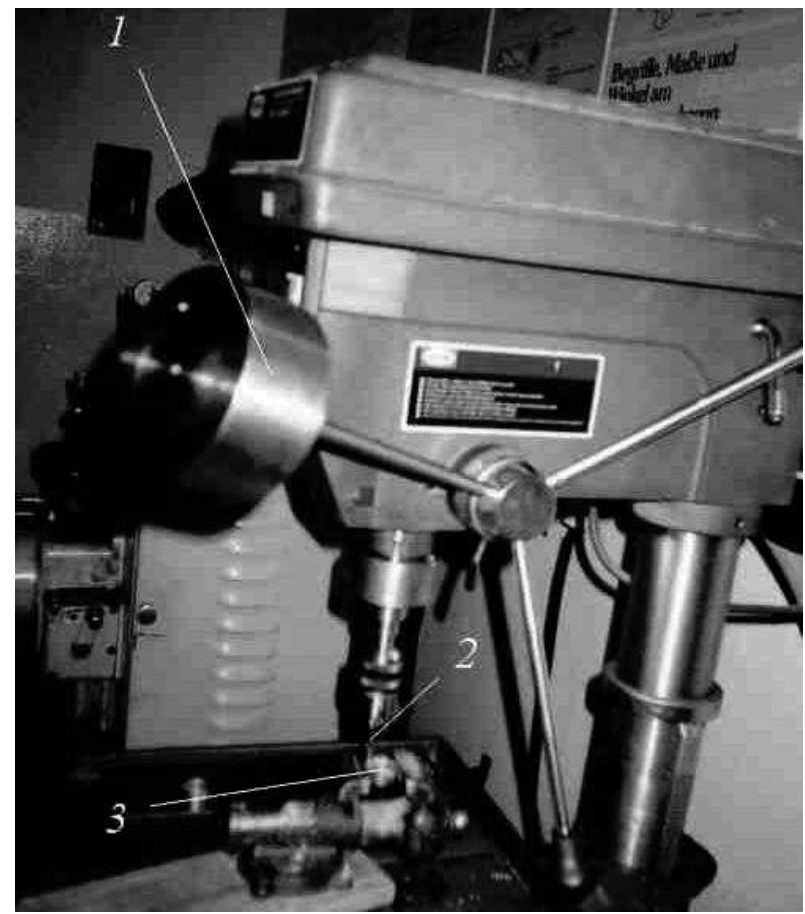

Fig. 19 Drilling by constant axis force on the drill. 1 - balance weight, 2 -drill, 3-workpiece.

A number of experimental methods to determine relative material machinability have been developer to present orientation data for the selection of cutting 
conditions [8],[9],[12],[15],[21]. On the base of experimental verification of several methods, one of the reliable ones can be considered the test of drilling with constant axis load, it means constant axis force $F_{\text {fk. }}$.

Fig.19 shows practical arrangement of the test. With the help of the balance weight, a constant drill load is created (when using the balance weight on the lever, drilling must always start in the defined balance weight position).

It is necessary to measure machining time necessary for drilling one opening into a flat sample with defined thickness. Then the machinability coefficient looks as follows:

$$
K_{\tau_{s}}=\frac{\tau_{\mathrm{s} 1}}{\tau_{\mathrm{se}}}
$$

Tab. 1 presents an example of comparison of machinability of certain steel kinds according to time necessary to drill one opening.

Tab. 1 Example of time necessary to drill one opening into the developmental steel samples

\begin{tabular}{|l|l|l|}
\hline $\begin{array}{l}\text { Steel sample } \\
\text { mark }\end{array}$ & $\tau_{\mathrm{s}}, \mathrm{s}$ & $\begin{array}{l}\text { Average value } \\
\tau_{\mathrm{s}}\end{array}$ \\
\hline $100 \mathrm{Cr} 6$ & $50 ; 46 ; 44 ; 40$ & 45 \\
\hline $100 \mathrm{Cr} 6 \mathrm{Nn} 6$ & $48 ; 48 ; 50 ; 46$ & 48 \\
\hline $42 \mathrm{MnV7}$ & $48 ; 45 ; 45 ; 42$ & 45 \\
\hline E360 & $86 ; 84 ; 82 ; 84$ & 84 \\
\hline C45 & $96 ; 78 ; 84 ; 80$ & 84.5 \\
\hline
\end{tabular}

The table presents high sensitivity of the test and acceptable dispersion of measured values.

\section{Conclusion}

The choice of cutting conditions $\left(v_{\mathrm{c}}, f\right)$ to secure economical machining requires to know exactly the relationship between cutting conditions and results of machining. Recent assortments of cut and cutting materials requires preventive experimental verification of such dependences. The the detailedexperimental dependencies of $T-v_{\mathrm{c}}$ represent a new perspective on the real durability of tools in operation. Also obtaned the dependences Rz-f and Rz- $v_{c}$. Finally, a reliable method for determining the relative machinability of materials is preferred. Obtaining new - more exact dependeces for cutting forces, quality parameters of machined surfaces, cutting tools durability, present the disposition for the effective production of machine parts. The paper forms the methodology of study and presents new approaches to the observation of output characteristics of machining in relation to cutting conditions.

\section{Acknowledgement}

This work was supported by the Slovak Research and Development Agency under the Contact No. APVV-18-031.

\section{References}

[1] BLAŠKOVIČ, P., BALLA, J., DZIMKO, M. (1990) Tribológia. Bratislava: ALFA,1990, 360 s., ISBN 80-05-00633-0

[2] BOBROV, V.F., et all. (1967) Razvitije nauki o rezanii metallov. Moskva: Mašinostrojenije, 1967, 414

[3] BUDA, J., BÉKÉS, J. (1967) Teoretické qáklady obrábania kovov. Bratislava: ALFA, 1967, 698 s.

[4] DEGNER, W., LUTZE, H., SMEJKAL, E. (1989) Spanende forming. VEB Berlin, 1989

[5] DLOUHÝ, M., HOUDEK, J., KOLOC, J. (1964) Slinuté karbidy pro obrábèní. Praha: SNTL, 1964, 313 s.

[6] DMOCHOVSKI, J. (1978) Podstavy obróbki skrawaniem. Warszawa, 1978, $586 \mathrm{~s}$.

[7] DUPLÁK, J. (2014) Nové analytické vyjadrenie $T-v_{c}$ závislosti pre rozličné rezné materiály.Prešov FVT TUKE, Dizertačná práca, 2014

[8] GENSKÝ, R. (1966) Metal Cutting Operations. Leipzig: Edition Leipzig, 1966, $191 \mathrm{s.}$

[9] GLEBOV, S, F. (1933) Teorija najvigodnejšego rezanija metallov. Gosmašmetizdat, 1933.

[10] GRANOVSKIJ, G. I., GRANOVSKIJ, V. G. (1985) Rezanije metallov. Moskva: vyššaja škola 1985, 304 s.

[11] GRZESIK, W. (1998) Podstany skawania materialow metalonych. Warszawa: Wydawnictwa Naukowo-Techniczne, 1998, 380 s.,ISBN 83-2042311-2

[12] HOLEŠOVSKÝ, F. et all. (1991) Materiály a technologie obrábèní. Ústí n. Labem, UJEP, 1991, $250 \mathrm{~s}$.

[13] HOSHI, K., HOSHI, T. (1969) On the metal cutting mechanism with the built-up edge. Mem.Fac. Engng. Hekkaide University 12, č.3, 1969

[14] KACZMAREK, J., WOJCIECHWICZ, B. (1995) Zmjany w strategii badaň eksloatacyjnej warstwy wierzchniej. Tribologia č. 6, 1995, s. 629 -654 .

[15] KALPAKJIAN, S. (1989) Manufacturing engineering and technology. New York: Addison Wesley Publishing Company, 1989, pp.1999, ISBN 0201-12849-7

[16] KOVAČ, P., MILIČIČ D. Rezanje metala. Novi Sad: Univerzitet u Novom Sadu, 240 s., ISBN 86.899-0015-1

[17] KUNDRÁK, J., PÁLMAi, Z. (2019) The Change of Tool Life in a Wide Range of 
Cutting Speeds in Hard Turning. Manufacturing Technology, April 2019, Vol. 19, No. 2

[18] LOLADZE, T. N. (1952) Struそ̌koobrazovanije pri rezanii metallov. Moskva, Mašgiz, 1952

[19] MASUDA, K. (1970) Compressive strenght of the cutting edges of the WC-Co cemented carbides. Bulletin ASME, 13, č. 56, 1970

[20] NOVÁK, M., HIROSHI, K., OHMORI, H. (2013) Differences at the Surface Roughness by the ELID and Grinding Technology. Manufacturing Technology, 2013, vol. 13, No. 2

[21] OPITZ, H., SCHILLING, W. (1967) Untersuchung der Verschleißreaktionen bei der
Bearbeitung von Stahl mit Echnellarbeitsstahlwerkzeugen. Forscbungsber Landes Nordhein-Westfalen, 1967, Nr. 1796, 95 s.

[22] POLAČEK H, P, P., CHVOJKA, P., DROBÍLEK, J. (2014) Dynamic Forces in Unstable Cutting during Turning Operation. Manufacturing Technology, March 2014, Vol. 14, No.1

[23] PŘIKRYL, Z., MUSÍLKOVÁ, R. (1982) Teorie obrábèni. Praha: SNTL, 1982, 235 s.

[24] TAYLOR, F, W. (1906) On the art of cutting metals. Transaction of the ASME, 28, November 1906, s. 31-279, 281-350

[25] TIME, J. A. (1870) Soprotivlenije metallov $i$ dereva rezaniju. Petresburg 1870 